\title{
Accounting, performance measurement and fairness in UK fresh produce supply networks
}

\author{
Lisa Jack ${ }^{a}$ (corresponding author), Raquel Flórez López ${ }^{b}$ and Juan Manuel Ramón Jeronimob \\ a Portsmouth Business School, University of Portsmouth, Richmond Building, Portland \\ Street, Portsmouth PO1 3DE, United Kingdom. Telephone: +44 2392844136 Email: \\ Lisa.Jack@port.ac.uk \\ ${ }^{\mathrm{b}}$ Department of Finance and Accounting, University Pablo de Olavide, Ctra. Utrera, Km. 1. \\ 41013, Seville, Spain. Telephone: +34 954349177 Email: rflorez@upo.es; jmramjer@upo.
}

\begin{abstract}
Food systems in Europe, North America and Australasia are dominated by a small number of supermarkets supplying over $70 \%$ of the food consumers buy, and the model is being translated into other markets such as the Middle East and Asia. Relationships between suppliers and supermarkets are contentious in all such systems. Here, interviews were carried out with representatives of three major grower-packers supplying between them around $50 \%$ of the UK's fresh produce. We were interested in three questions, namely: how performance measurement, risk management and communication of accounting information are used by intermediaries in an allegedly unfair commercial environment; the extent to which the accounting and control practices observed support perceptions that suppliers in supermarket-dominated supply networks are treated unfairly; and what accounting and control practices would be indicative of fair commercial relationships? Researchers in the cross-disciplinary literature use John Rawls' theories of 'justice as fairness' in this context. Recent developments in business ethics and philosophy apply his theories to questions of relational power and fairness in commercial relationships. We follow these writers to understand where, if at all, the perceived unfairness of these food systems lies. Our empirical work and analysis can make an initial contribution from the discipline to this debate, because it has the potential to show how accounting and control practices are at the centre of the fragilities of the wider system, and of possible remedies.
\end{abstract}

Keywords: supermarkets, supply networks, performance measurement, relational justice

\section{Introduction}

Supermarkets in developed countries such as the UK offer fresh produce at low prices, 24 hours a day and 363 days a year. The management of this supply is co-ordinated mostly through intermediary firms and co-operatives known as 'grower-packers' who in turn co-ordinate large numbers of growers in the UK, Spain and other countries, to meet orders and service level agreements. Consumers are promised low prices, and it is difficult for the intermediaries and other growers to realise more than a 1-2\% net margin on turnover [1]. Consequently, wages paid are low and there is little evidence of owner-managers in what are largely family-run businesses being able to take dividends from the business. In fact, many businesses are supported by Directors' loans and there is little room for reinvestment without taking on substantial loan finance. Despite some local differences, similar situations exist in other countries where food systems are dominated by a small number of supermarkets, particularly in the USA, Canada, Europe and Australia (Burch and Lawrence, 2007; Nicholson and Young, 2012).

We carried out interviews with representatives of three major grower-packers supplying between them around $50 \%$ of the UK's fresh produce. Initially we were interested in how intermediary businesses in food supply networks established management controls, performance measurement 
and risk management between themselves and their supply network partners. From the available data, it became very clear that the constraints the intermediaries faced in terms of using information from control systems in negotiations with supermarkets (their major customers) were contextualised by them in terms of unequal relationships and allegedly unfair practices. Similarly, the managers construed their dealings with suppliers (and the suppliers with the grower-packers) in terms of their attempts to be fair. In the cross-disciplinary literature on supermarket supply networks, gaming and fair practice are frequently used in interpretations of intra-network relationships. There is documented evidence that supermarkets use their power to place sanctions, including complete delisting, on suppliers in fresh produce when those suppliers challenge prices, additional payments or unrealistic orders. (see Nicholson and Young (2012) for a detailed discussion of such sanctions).[2] The situation in fresh produce is very similar to the opportunistic and adversarial nature of transactions reported by Bowman et al. (2013) in supermarket supply chains for pork and in Free's $(2007,2008)$ investigations into potentially coercive practices related to category management. It also resonates with practices by intermediaries in the fast fashion garment industry (Neu et al., 2014), an industry that is also disintegrated though not to the extent that food supply chains are fragmented and non-integrated (Bowman et al., 2013; Callado and Jack, 2017). The seminal paper exposing the use of accounting and IT by supermarkets to gain power over producers is Frances and Garnsey (1996). However, the emergence of category management and the rise of 'super middlemen' such as the meat processors in Bowman et al. (2013) and the grower-packers in our study at that time were already altering practices in the field. Our contributions are to extend this sparse literature on intermediaries by providing further empirical evidence of accounting and control practices in such firms, and to extend discussions in the interdisciplinary literature about the fairness of practices in the food industry.

At first, this appears to be a question of trust and transparency. It is well-established that these are lacking in the agriculture and food industry, and any theoretical interpretation based solely on identifying levels of trust or transparency is unlikely to lead to any substantial new insight (Burch and Lawrence, 2007; Jack, 2007; Bowman et al., 2013). Allegations of unfair treatment of fresh produce suppliers are found in all food systems based around supermarkets, along with perceptions that profits and value are not shared equitably, and that systems are unsustainable. Among many other issues, these systems rely on a low wage economy, are implicated in social issues of poor nutrition and obesity, and are subject to extreme pressures from investor-analysts to increase share returns by reducing prices (for example, see Ghosh, 2010; The Daily Telegraph, 2013). The question of fairness in the supply of food is fraught because it needs be taken in the context of whole social systems.

We chose John Rawls' 'justice as fairness' as the basis of our theoretical analysis for three reasons. First, because it is already present in the cross-disciplinary literature as an explanation of the nature of unfairness in the industry (Duffy et al., 2003; DuPuis et al., 2011; Duffy et al., 2013). However, Rawls' concepts are used simplistically as these studies address only the question of whether distributive or procedural injustice is the better descriptor, or in the case of DuPuis et al. (2011) applied to the different question of local food. They do not take fully into account Rawls' (2001) last restatement of the principle of 'justice as fairness'. Our case study presents an opportunity to discuss the extent to which Rawls' work explains fairness in the industry and in accounting practices.

The second reason is that although contentious, Rawls' theory does offer a view on how to create more equal and just societies. There is the profound question here of whether a few should profit from food supply systems that can be construed as depressing the wealth, health and social opportunities of others, which is in line with the types of questions that Rawls addresses in his theory (Rawls, 2001; Guthman, 2011). This complex question is being seriously researched and debated in academic and policy circles under the banner of 'food security', but very few accounting academics have entered this global debate. Our empirical work and analysis can make an initial contribution from the discipline to this debate, because it has the potential to show how accounting 
and control practices are at the centre of the fragilities of the wider system, and propose possible remedies.

The third reason is that since the completion of our study, there have been publications in business ethics and philosophy that question relational power and fairness in commercial relationships. These address critical unfinished elements of Rawls' (2001) theory of 'justice as fairness' (Heath et al., 2010; Néron, 2015; Singer, 2015). The authors consider the nature of relational resources, business ethics, power and justice in egalitarian systems. The nature of relationships between our case companies, their customers and their suppliers was brought up many times by our interviewees. They felt it affected whether they were or were not able to use information from accounting and control systems. Therefore, our findings have the potential to clarify what might be meant by 'justice as fairness' in commercial relationships, given that accounting and control are a significant component of commercial activity.

To address these complex questions as straightforwardly as possible, the paper is structured as follows. We look first at the rather sparse accounting literature on supermarkets and on intermediary businesses in other industries, and then at the evidence from other disciplines. This includes the critical emergence of category management in supermarkets' supply networks around 1996 , and allegations of unfair practices. This is followed by introductory comments on Rawls' 'justice as fairness' and the concept of the difference principle in relation to the 'least advantaged' in a system. This leads into a review of the recent work on relational resources, business ethics, power and justice, and how it relates to Rawls' 'justice as fairness'. This is followed by the methods, case study findings and concluding discussion.

\section{Literature Review}

There are very few papers in the accounting literature that deal directly with food supply networks or with intermediary businesses in supply chains. Inter-organisational management control in supply chains does have an extensive literature in accounting. These papers tend to be quantitative, functional studies of dyadic, relatively long-term relationships between partners in integrated supply chains (see, for example, Dekker, Sagakuchi and Kawai (2013); Fayard, Lee, Leitch and Kettinger, (2012)) The difficulty in relating these to our study is that food supply chains are characterised as being non-integrated and fragmentary (Callado and Jack, 2016). Even where there has been a longterm relationship between the grower-packer and the supermarket, or the supplier and the intermediary, it is very rare for there to be a long-term written contract for supply. There are service level agreements, but no obligation on either side to buy or sell to the other. More detailed accounts of supplier-customer behaviours in food supply chains are found in other disciplines, including organisation and production studies, marketing, geography and business ethics. Therefore, we include only papers from inter-organisational management control that relate closely to this study, and concentrate on those papers in accounting, management control and other disciplines that deal most closely with relationships in similar supply networks.

Interestingly, the three or four papers in the accounting literature relating to supermarket supply networks are also highly regarded qualitative studies of power relationships in accounting and management control practices. Because of changes in supermarket practices that occurred between each paper being published, the papers are presented in reverse chronological order rather than synthetically.

Bowman et al. (2013, p.301) present a vehement exposé of UK food supply chains based on a detailed case study of the pork processor Vion, which withdrew from the UK market in 2012. They draw attention to opportunistic trading and value extraction by the main UK retailers:

"...the big three supermarket chains in the UK directly adopt and indirectly encourage trader mentalities and opportunistic dealing up and down the vertically disintegrated meat supply 
chains, where everyone is trying to pass the risks and costs onto somebody else. The disintegrated chain creates motive and opportunity for the EU-wide meat supply chains as the UK processors and producers go out of business."

Important factors reported here are the lack of contracts in the fresh meat supply chain, and the propensity of supermarkets to play off suppliers against each other in search of the cheapest deals.

In other European countries, the ethos of co-operatives involving processors and producers mitigates the power that can be exerted by retailers. Bowman et al. (2013) also provide a contrast in the supermarket chain Morrisons (currently the fourth largest food retailer in the UK) who attempt to create shorter, long-term relationships with an integrated supplier base of UK partners.

They refer to Free's $(2007,2008)$ work on category management in UK supermarket retail chains. He focuses on whether collaborations between supplier and retailer could be best described as enabling or coercive. His cases are short supply chains in paper products and hair colourants. The relationships were long-term -one paper products firm had been a supplier for 20 years at the time category management was brought in. Both retailer and manufacturer worked with templates for detailed benchmarking among other mechanisms. The retailer freely admitted that "for us, a new product line is an opportunity to lever money out of a supplier". Both sides, however, saw category management as possible exploitation by the other partner, cutting into both narrow profit margins. The hair colourant company and their customer shared even price sensitive information. The collaboration lead to joint forecasting and increased efficiencies, new product development and profitability for both parties. Importantly, performance measures and benchmarks were used in both cases to prevent what the retailers saw as opportunistic exploitation by the manufacturer who might suggest product mixes for sale that increased their own profits but were not optimal for the supermarket [3].

Free also shows that the use by the supermarkets of category management and associated joint accounting mechanisms is aimed at creating co-ordinated competition between suppliers of similar goods. He found (2007, p.928):

"In spite of the normative overtones of the descriptors 'enabling' and 'coercive', it is not clear that retailers will necessarily wish to pursue enabling long-term relationships. Indeed, forms of close co-operative ventures are costly both in terms of direct investment and opportunity costs."

Free (2008), based on the same cases, explores the uses of open book accounting. Free sees trust as a discursive resource, defined as "the deliberate manipulation of claims to commitment, legitimacy, sincerity and clarity represent[ing] a sophisticated attempt to secure co-operation rather than the pursuit of trust generation" (2008, p.652). Rather than trust, he observed opportunism. Trust is better conceptualised, he feels, by "accommodative intentions", "reliability" and "commitment". The evidence presented by Free $(2007,2008)$ suggests that heavy-handed forms of accountability and the indiscriminate demands for open book accounting are unlikely to create trust. Moreover, OBA provides strong incentives for manipulating management accounting information and may induce unwillingness behaviours (Free, 2008).

Similar issues of opportunism and trust are raised in other supply chain contexts. Angdal and Nilsson (2010) found a link between purchasing strategies and open book approaches, and posit that open book accounting can only be successful if accompanied by a purchasing strategy. They say that (2010, p.164):

"...two conditions are necessary for success: (1) the supplier must trust that the buyer will not use cost and similar data to the supplier's disadvantage, and (2) the buyer must demonstrate that disclosed data are necessary to achieve joint benefits. In effect, the buyer should be accountable to the supplier." 
The buyers in Free $(2007,2008)$ would counterargue that the supplier ought not to manipulate information to achieve a higher price or a different mix resulting in an overall benefit or as the basis for a pitch to competitors.

Cross-firm collaborations aim to reduce costs (Cooper and Slagmulder, 2004). Incomplete contracting means the calculus expands to incorporate both bargaining costs, where the parties are acting in their own self-interest but in good faith, and opportunism costs, where they are acting in their own self-interest but in poor faith. The suggestion in the cross-disciplinary literature is that the conditions for opportunism rather than trust are evident in the fresh produce industry.

Frances and Garnsey (1996) observed the early stages of the reconfiguration of producer-distributorretailer relationships that Harvey $(2007$, p.59) later refers to as the "second revolution" in the UK food provisioning system. The first was the development of multiple retailing in the first half of the twentieth century. During the 1990s, supermarkets in the UK were developing quick response partnerships that would ensure supplies of fresh produce to meet customer demand on a just-intime basis. Collaboration was limited to provision of investments, accounting techniques and knowledge from supermarkets to upstream members of the supply chain. This maintained oligopolistic competition, keeping prices low while guaranteeing delivery of products. Limited personal interactions and key connections were established between closely coupled collaborators (Frances and Garnsey, 1996). The main drive was for producers to be accountable to the supermarkets, in systems that included sanctions for not meeting what we term 'on time in full to specification' requirements.

This has come about but rather than the supermarkets dealing with many producers, they deal with a small number of 'grower-packers' acting on behalf of themselves and associated growers. Supermarkets have become a type of multi-monopsony matrix where:

"...a few large suppliers subdivide themselves in order to supply a few large retailers on the one hand, while a given retailer sources its differentiated price-quality range from several of the same large suppliers, on the other" (Harvey, 2007, p.60).

This is a "very peculiar monopsony" (ibid., p.58), where the retailer has depth of control over the production, innovation, quality and packaging of fresh produce. Harvey (ibid.) goes on to note that:

"The depth of organisation and management goes much further than most concepts of integrated supply chain management... This is a feature typical of the distinctive innovation style of these economic power relations: the ability to trade in novelty and respond rapidly to fashions in the aesthetics of food."

The impact of Efficient Customer Response (ECR) - the name that quickly superseded the 'rapid response partnershipping' in Frances and Garnsey (1996) - was examined by Corsten and Kumar (2005, p.81), who said:

"There is a widespread belief among suppliers that ECR is just a convenient label for large and powerful retailers to continue doing what they have always been perceived as doing, namely, finding ways to pass costs back to the suppliers"

Suppliers have a perverse relationship with ECR. It provides some level of efficiency and recordkeeping, along with access to the market. But "Smart retailers take a bite out of the supplier's economic performance, yet suppliers are happier with what is left" (Ibid., p.90). This is more popularly termed 'profit snatching'. The retailer insists visible savings by the supplier are passed on to the consumer, reducing the suppliers' opportunities for reinvestment or value sharing.

There are parallels to food supply chains in the garment industries, particularly the cheaper, massproduced clothing sold through multi-national companies. Both Jeacle and Carter (2012) and Neu et al. (2014) obtained access to intermediaries and observed the accounting practices in place at 
intermediary manufacturing firms and head offices. Neu et al. (2014, p.344) note that "within lowprice apparel production chains, some participants are more able than others to encourage and/or demand the adoption of specific accounting practices". Accounting is used within 'sweatshops' to achieve the low target costs needed within the low-cost apparel industry and to meet the demands of continual new product development. There is some integration of accounting use and practice between retailers, designers, the buyers who act as the intermediaries and the workplaces. What are very apparent are the low wages paid to those making the garments and the appalling working and living conditions of those working in less developed economies. Workers may acknowledge that the conditions are better than those in other occupations (including agriculture), but they are still degrading.

The processed food industry has parallels in terms of new product development, budgeting, timescales and pressures. Fresh produce, however, is far more problematic. The produce has a short shelf life, but takes time to grow and is subject to adverse diseases and weather events. Greenhouse conditions may allow some products (typically salads) to be grown quickly to specification, but it is not an exact science. If produce is grown in fields, then crops have to be rotated and the availability is highly dependent on the weather. There is an element of new product development (in plant breeding, different agronomies, varying specifications), but not in the same rapidly changing environment as fashion (Jeacle and Carter, 2012; Neu et al., 2014), paper or hair products (Free, 2007, 2008) or processed foods (Abdel-Kader and Luther, 2006).

The problem of dominant retailers and the monopsonies created in the last twenty years has been addressed by Cox and Chicksand (2005) and Hingley (2005), among others, in marketing, organisation studies and geography. They state that upstream businesses must be opportunistic and play the market, or develop their own premium products to capture value, or must learn to make the most of what leverage they have in terms of offering exceptional quality and service. Otherwise, as Cox and Chicksand (2005, p.661) say:

"...upstream members of the chain will be forced either to exist in their current state of uncertainty, or be forced to align themselves operationally with particular multiple retailers, integrated processors and buying agents and trade low commercial returns for guaranteed demand operationally. That is to accept the role of a willing supplicant...".

Looking primarily at lean management practices in the fresh/frozen beef supply chain, they found that whilst lean principles offered positive outcomes for the multiple retailers, they may have resulted in high levels of dependency on supermarket buyers and declining profit levels, a situation also recorded by Bowman et al. (2013). Hingley (2005) sees the current power of the supermarket buyers as inevitable, and that to create sustainable businesses food intermediaries and producers must either adapt to the games played, or trade outside the supermarket system.[4]

$\backslash$ Grimes (2005, p.563) addresses the question of large retailer buying power and its effect on small atomistic suppliers, pointing out how the latter have:

“...heightened vulnerability linked to the sunk costs incurred in carrying out a chosen business or profession... Power buyers tend to target atomistic sellers whose sunk costs make it less likely that they will reduce the volume of their sales simply because the power buyer insists on a discounted price".

This vulnerability increases when the seller deals in perishable goods, where there are fewer options for alternative sales in the time available. Grimes (2005) is concerned with the failings in US law to curb abuses of gatekeeper power by companies such as WalMart and Price/Costco (see also Fishman, 2006). This is partly because the existing law is skewed towards seller abuses and consumers in monopolies. 
Cox and Chicksand (2007) explain that supermarkets have come to have a 'Janus' facing role in society, by being both monopolies when facing consumers and monopsonies when facing buyers. The important question is how long sellers can go on providing exceptional quality and service for low returns. Grimes (2005, p.575) states:

"Suppliers whose sunk costs force them to live with a low rate of return on their investment are far less likely to make a future investment in the industry. Their experience may, in turn, deter others from doing so."

Questioning suppliers' engagement with retailers' customer response strategies and requirements for innovative products, Duffy et al. (2013, p.25) conclude that:

“...buyers need to make themselves attractive to suppliers, by offering value to suppliers not just in terms of financial benefits, but also in terms of strategically significant non-monetary rewards one such source of value is how fairly suppliers feel they are treated."

Earlier, Duffy et al. (2003) identify one source of unfairness as the number of unnecessary costs that retailers imposed on suppliers (such as compensation for shelf space and discounts), whilst Duffy et al. (2013) examine the concepts of distributive and procedural justice in the context of supermarket suppliers. They note that suppliers were more exercised by procedural injustice, defined as exclusion from decision-making processes (including pricing), than by distributive justice. The latter is defined as where the "more powerful partner realises that they have some responsibility for the profitability of the less powerful" (ibid., p.572). This is seen as out of reach in a monopsony, whereas procedural justice is more attainable. Fearne et al. (2005) found suppliers perceive best practices to be prompt payment, accurate/fair pricing and bilateral communication. Worst practices are retailers not accepting any cost increases in the supply chain, wanting an increased margin for themselves (on price and shelf life of the product), not allowing price increases despite increasing input costs, forcing prices down and the discourtesy of not allowing two-way communications.

In 2014/15, an accounting scandal in Tesco plc in the UK highlighted the extent to which supermarkets rely for their profits on what is termed 'commercial income' taken from suppliers. Commercial income underpins many of the perceptions of unfairness in the industry and demonstrates the extent to which buyers in a category management system can exert power over suppliers. This ranges from listing and slotting payments, through to penalties for deliveries not on time, in full or to specification. It also includes bonuses and rebates paid to the supermarket for performance on marketing and selling volume of a supplier's goods, as well as the compensation payments (Duffy et al., 2003; Nicholson and Young, 2012). These practices became established in the 1970s (Clarke et al., 2002; Poddar and Donthu, 2011) and until recently were considered 'under the radar' of consumers (The Economist, 2015).

Tesco plc was found to have breached the UK Grocery Code of Practice set up following a commission into fair practice in supermarkets in 2008. Furthermore, they were investigated by the Financial Reporting Council for overstating profits by $£ 263$ million through anticipating commercial income in the form of marketing and distribution fees (The Economist, 2015) and three senior former members of staff went to trial in October 2017. The Grocery Code Adjudicator found evidence of delayed payments through data input and duplicate invoicing, as well as obstruction in settling disputed payments. More worryingly, she found that buyers were working toward budgeted margin targets embedded in 'joint business plans' (JBP) with suppliers and there was evidence to show that: "Payments to maintain the margin target were requested from suppliers by Tesco regardless of whether the planned growth had been achieved and regardless of whether Tesco had delivered on its own JBP commitments" (GCA, 2016, paragraph 7.5). Tesco plc has taken steps to demonstrate compliance with the code, including a stated commitment to end margin-based negotiations (Stones, 2015). 


\section{Using John Rawls' 'justice as fairness' as a theoretical framework}

There is, then, substantive evidence of unfair practices occurring in the industry. Theoretically, Duffy et al. (2013) draw on concepts of distributive and procedural justice from the work of John Rawls (1971). Recent scholars in business ethics and political philosophy are drawing on Rawls' work, particularly the volume published in 2001 before he died entitled Justice as Fairness: a Restatement, to explore the notion of relational justice. Given that previous work in accounting has established the power relationships and types of accounting practices used in retail supply chains, we decided to explore the use of Rawls' concepts to test allegations of unfairness in the industry. Duffy et al. (2013) draw on his difference principle in a limited way, and suggest suppliers are most exercised about the unfair relationships they have in terms of procedures and practices evinced by supermarket buyers. We wanted to use Rawls' ideas to draw out more fundamental aspects of unfairness in food supply systems and to find out more about where accounting and management control practices might fit into conceptions of a just society.

The few accounting applications of Rawls' theory sit within discussions of financial reporting and conceptual framework analyses (for example, Power, 1992; Archer, 1996). The most extensive study in this area is by Flower (2010), who looks at distributive justice and the extent to which it is the responsibility of firms to ensure this.

In Justice as Fairness: a Restatement, Rawls (2001) explains that the primary aim of his life's work is to establish what it means to have a well-ordered society based on a fair system of co-operation. He acknowledges the "very considerable idealisation" involved in this undertaking (ibid., p.9).[5] Rawls advocates a form of social contract based on fair and equal opportunity, and social co-operation.

There are two aspects of Rawls' theory that are most relevant to our discussion. These are from the principles of 'justice as fairness', which he re-stated in 2001 to say:

(a) "Each person has the same indefeasible claim to a fully adequate scheme of equal basic liberties, which scheme is compatible with the same scheme of liberties for all.

and

(b) Social and economic inequalities are to satisfy two conditions: first, they are to be attached to offices and positions open to all under conditions of fair equality of opportunity; and second, they are to be to the greatest benefit of the least-advantaged members of society (the difference principle)" (Rawls, 2001, pp.42-43).

The question of who are the least advantaged is critical in any discussion of food systems because it relates to the deeply political question of cheap food. The immediate assumption is that impoverished consumers are the least advantaged in the system. However, reading Rawls more closely, the obviously disadvantaged in society (the disabled, unemployed or those in ill-health) are not who means.

Freeman (2007, p.106) explains this further:

"Rawls deals with the homeless, beggars and the unemployed under separate principles other than the difference principle. By 'least advantaged' Rawls means the least advantaged working person, as measured by an income he/she obtains for gainful employment. So the least advantaged are, in effect, people who earn the least and whose skills are in the least demand - in effect, the class of minimum wage workers."

The question Rawls raises is: "what are the most appropriate principles for designing basic economic institutions and distributing the product among socially productive and freely associating equal citizens, each of whom is willing to contribute his/her fair share to social co-operation?" (ibid.). 
Hence, in the food supply system, the least advantaged are not the impoverished in general but the suppliers who are on the brink of insolvency or in poverty despite sales of produce, and the employees who are on the minimum wage or, in other countries, exploitation wages. These are substantial groups of people. A study in 2015 showed that some 1400 of the UK's 5800 SME food manufacturers and suppliers were in some form of financial distress (Fredenburgh, 2015). Average farm incomes are below the average household income for the country and for overseas suppliers, and the figures suggest that many remain in poverty despite various fair trade initiatives (Lines, 2008). [7] The poorly nourished and those on subsistence wages are self-evidently not offered fair equality of opportunity in society. The more problematic question is that of the intermediaries and their suppliers' lack of return on investment in assets and management. They have the opportunity to make a living, but others in the system for less personal investment (such as shareholders in multi-national food companies) get greater rewards.

At first glance, the issue would seem to be one of distributive justice with profits upstream being eroded, wages kept low and inequalities in who has access to nutritious food. It could be argued that at least there are profits, wages and food available, and that the rules of the game are understood. However, recent scholarship in this area has looked beyond distributive justice to define unfairness. Rawls posits that equality is not a matter of everyone having an equal share of wealth or material goods and 'justice as fairness' is based on fair equality of opportunity. He extends his definitions of justice to include procedural justice, a term which he later re-presents as a part of "background justice" (2001, p.54). Background regulations maintain justice within the basic structure, and this allows everyone to follow the "publicly recognized rules of co-operation" (ibid.) making whatever distribution that results acceptable. He envisages an ongoing scheme of fair cooperation, that is freed from keeping track of the relative positions of individuals to one another.

Rawls' conceptions of distributive and procedural justice have been criticised by Sen, Nussbaum and others because of the notion of distributive justice. What constitutes a fair equality of opportunity and how are goods to be distributed? In place of primary goods and resources, they propose a political philosophy based on capabilities and insist that it should be possible for a list of capabilities to have definite content. Furthermore, Nussbaum (2003, p.56) argues, a Rawlsian framework for a just society might be made to work in terms of "a vision of social justice that will have the requisite critical force and definiteness to direct social policy". Other writers disagree, finding Rawls' theories untenable (for example, Nozick, 1974; Singer, 2015). 'Justice as fairness' is also criticised by those who feel the corporation (as a fundamental element of social life) cannot be conceived in the basic structure and therefore Rawls' vision remains utopian (Hsieh, 2009; Heath et al., 2010; Hunt, 2010). However, we cannot provide a solution to the deficiencies in Rawls' work, but use its premise of 'justice as fairness' to evaluate the allegations made in the industry of unfair practices and to put them in the context of social food systems. We see the question of the role of corporations in fair societies (as embodied in food systems) as a necessary discussion, but one which is beyond the scope of this paper. The nature of relationships between supply network partners leads onto recent developments of Rawls' ideas.

Over the past ten years scholars have revisited the notion of distributive justice within ideal and nonideal societies (for example, Anderson, 2009), including within commercial and economic settings (Anderson, 2007). As Néron (2015) points out, Rawls openly acknowledged that he was unable to solve this aspect of his theory (essentially, whether market capitalism can be part of a fair society) and despite various calls to do so, business ethicists and egalitarian philosophers are just beginning to get to grips with the conundrums involved (Hsieh, 2009). In doing so, they have developed the concept of relational justice in ways that are very relevant to our cases and potentially to any study of the roles of accounting in fair and equal societies. This "relational turn" in political philosophy (Néron, 2015, p.116) addresses the gap between corporate governance $\&$ business ethics and theorists of just societies, by enabling discussions about the adversarial nature of markets and the command structures of organisations. 
Anderson, an acclaimed political philosopher from the USA whose work takes in arguments from both Dewey and Rawls, gives this straightforward explanation:

"Relational equality is about conceiving of society as, ideally, a place where people can meet and interact with one another on terms of equality. Concerns about distribution can be derived from relational equality, but the relational egalitarian agenda is much wider than distributive concerns alone. For example, one broad set of concerns that relational egalitarians have is to do with relations of domination and subordination" (Anderson and Pearce, 2012, p.188).

Taking the standpoint of the least advantaged or obviously discriminated against (much of Anderson's work is about racial inequalities) from which to conduct empirical analysis, avoids the issue of judging an ideal, just society from the position-practices of those who are not disadvantaged (Anderson, 2009, 2010). The key, as she explains, is that:

"When the rules have been rigged so heavily to favour people who have privileged access to finance and capital at the expense of ordinary working people, then that suggests that the interests of ordinary working people haven't been counted equally with those of other groups in the way we've designed this game" (Anderson and Pearce, 2012, p.189).

In food we are, as Guthman (2011) says, at the limits of capitalism and its games. She argues that:

"For along with making the economy thoroughly dependent on (low-cost) consumption and exacerbating inequalities in wealth, neoliberal logics have helped to produce many of the food qualities and environmental features associated with obesogenesis." (ibid., pp.172173).

The terms 'relational equality', 'relational resources' and 'relational justice' are used to discuss similar issues. For Cordelli (2015, p.107), "fair equality of relational opportunity requires, as its own pre-condition, relational equality understood as the absence of social relations of domination, segregation, and hierarchy" (see also Anderson, 2010). Individuals should have access to an "overall adequate level of each relational resource, rather than particular relationships" set against some standard of "human flourishing" (ibid., p.108).

Néron $(2015$, p.114) sets out a framework for the audit of relational justice, being the "qualities of business firms and markets that relational egalitarians would tend to see as necessary conditions for just economic relationships, hierarchical structures, and transactions". These include voluntariness, the real possibility of exit, voice, sphere differentiation or an element of bureaucracy (see Anderson and Pearce, 2012) within an organisation or system, as well as external standards that enforce rights and obligations to maintain fair equality of opportunity.

We show that the concepts of relational justice can be applied in investigations into the nature of unfairness or otherwise in the food industry, and explore the role of accounting and control therein.

\section{Research Methods and Data Collection}

The work presented here is one of several papers and reports from a project investigating performance measurement and risk management in intermediary food supply businesses.

Five groups of interviews were carried out with intermediary food companies in the UK and Spain, based on interviews with key managers, secondary companies, auxiliary industries, independent brokers and dealers, along with a review of financial data and prior research in related areas (such as value chain management and the role of retail buyers). A total of 29 interviews were conducted, lasting an average of one hour each. The interview data was, in most cases, recorded and then transcribed, although in three meetings notes were taken and written up as memoranda. The 
majority of interviews were carried out on-site and included one major site tour, but the remainder were telephone interviews at the request of the interviewees.

The interviews were conducted using a semi-structured interview identifying key factors drawn from existing literature. The main sections covered the sharing of resources with customers/suppliers, perceptions of risk, supply chain collaboration, risk and change management, performance management systems, accounting systems, rewards and incentives. Transcripts and memoranda were coded using NVivo software, first identifying free codes and then grouping these under four headings (tree/parent codes) based on the four areas of intermediary dependencies, perceived risk, negotiation of inter-organisational performance measures and pro-active performance management. Reports generated by NVivo were then subjected to close reading to identify key factors for further analysis.

The initial findings and reports from the research study have been presented on four occasions to practitioner audiences, and feedback at these events from other intermediaries and growers has supported our interpretation of the industry and the supply chain practices within it.

\section{The grower-packer businesses in our study}

The 'UK Firm' supplies around $25 \%$ of all fresh produce sold in UK supermarkets, with an annual turnover in excess of $£ 220$ million. They grow some produce themselves, but mainly co-ordinate around 50 suppliers in the UK and Spain to ensure supply across fruit, vegetables and salad categories. They supply all the multiple retailers in the UK. The firm is a typical example of the grower-packer businesses in the UK which began as family farms several generations ago, but which took the opportunity to expand in the 1990s by developing the packing, marketing and distribution side of their businesses in line with the changing demands of UK supermarkets. Members of the original family have active top management roles in the business.

The 'UK/Spanish Firm' is more complex. Its core is a co-operative of six companies based on the Spanish mainland and Canary Islands. They mainly distribute and market salad across Europe through limited liability companies incorporated in the UK and the Netherlands. The six main partners are in turn supplied by co-operatives of growers and the customers are both supermarkets and food preparation companies (e.g. pre-prepared sandwich makers). The group has a turnover of around $\mathrm{f} 25$ million per annum.

The 'Spanish Firm' is a family business with more than 30 years of experience. They deal with more than 9,000 growers and 2,000 clients, forming a complex group in which the company leads the commercial process with clients and input suppliers. Currently, the company has a turnover of around $£ 32$ million and the main co-operative of 100 growers has a turnover of $f 5$ million per annum. There are six packing centres for vegetables and fruit, dealing daily with hundreds of growers from greenhouses and outdoor sites. Over time, their business has moved towards foreign markets and high-quality standards, making them a leader in southern Spain. The company itself focuses on packer-distributor activities; however, they grow some new varieties or special orders from clients that may not be profitable for growers. They developed a revolutionary benchmarking process ten years ago, when a second packing centre was opened, for co-operatives of growers associated with the company.

Other interviewees includedkey managers, brokers and dealers from 12 different organisations. These represented a wide range of growers (mostly export oriented), three auxiliary companies of the food industry, a seedling nursery, a broker and two growers' associations. This mix of companies provided some validation of the main conclusions from our case study companies.

\section{Findings}

\section{Supply network relationships}


What is difficult to get across is how frenetic this industry has become. One Director described it as "a dog eat dog world... we are all working for next to nothing and everybody is out for the next opportunity". Finding time for the interviews was difficult; all were squeezed between engagements and one took place with the interviewee using a hands-free carphone whilst driving between meetings. However, the style of business in both the UK and Spain suited the grower-packers to some extent:

"There is always somebody in the business with a customer. Very rarely a day goes by when we haven't got someone with a customer... The best way we can sell our produce and our business, and the way we are different from other companies, is to have people here to see it and feel it and touch it and smell it" (Director, UK Firm).

A Spanish supplier of the UK Firm attested that "the foundation of everything is good communication" and said that when a problem arose with their hauliers due to pending strike action by drivers, they were able to speak to the intermediary (UK Firm) who negotiated the logistics with their customers. In turn, the managers in the UK Firm make frequent visits to suppliers, with one saying "a day in the office is a wasted day for me".

All the grower-packer-distributor businesses here are owner-managed, and in all cases the owners are active managers. There are very few fixed supply chains; relationships within the networks shift on an almost daily basis and there are very few written contracts. We were told that the intermediaries preferred to work with relationships rather than with contracts. A simplified explanation of the system is that supermarkets have service level agreements with the intermediaries, but not specific contracts for supply in particular categories. The supermarkets provide specifications for the quality, presentation and labelling of produce negotiated by the category buyers. Orders and deliveries are based on consumer forecasts, which may be altered at very short notice. This frequently disrupted operations but such orders were usually fulfilled. The intermediaries are required to meet the specifications and price offered; in only a very few cases will they contest the price. Their problem is that fresh produce, of course, takes time to grow. Crop rotations must be observed and, for premium produce, techniques such as trickle irrigation need to be put into place. The intermediaries work with their suppliers up to two years in advance to ensure that the land, varieties and technical aspects such as irrigation are in place to produce crops that will meet quality requirements and consumer demand. There were several anecdotes of how buyers from supermarkets appear to fail to grasp these points, making demands for produce in unfeasible timescales and seasons.

There is a question about whether the practices observed between retail customers and the intermediaries (as opposed to the practices used within intermediary firms and with their suppliers) could be termed 'coercive'. Certainly, there were specific pressures surrounding the price asked by customers which related to marginal costing. For example, a Director in the UK Firm said:

"Let me give you an example: you get a really big packer for one really big supermarket, one with over 30\% share, and they [the buyer] will get a phone call from a smaller one with a 3 or $4 \%$ share and they will think 'we can run that lot off the back of overheads and we can give them a cheaper quote'. That quote before you know it then becomes the normal price."

The UK/Spanish Firm representative agreed, saying "If they ask is a quantity of product per week serving a specification which tends to vary little from year to year, there is always a negotiation of price, that always, it always tends to be lower".

Intermediaries state that there is some competitive advantage in the creation and retention of longterm relationships, based on quality and reliability, as a means of survival in an industry where returns are very precarious. The business model adopted by intermediaries is to develop such good 
relationships that the best growers will want to work with them and supply them over long periods. As one Director said: "we do quite a lot really in terms of agricultural support and business support, business development...". Considerable effort is put into these relationships to provide value, with the aim of making price a secondary issue. One explanation of their strategy (which was similar across all three of the companies in the study) was that:

"We can't afford to pay more money than anyone else, but we need to attract the best $25 \%$ of the growers... to want to supply us and not because they have to, I want them emotionally engaged with us..." (UK Firm).

Whilst supermarkets might also claim this, one interviewee stated clearly that their own aim was to treat their suppliers better than they themselves were treated by the retailers. They also aim to move away from the previous wisdom that middlemen are only there to exploit the growers and carve out profits. The only way, directors from each of the three firms contend, to have any negotiating power with multiple retailers is through size and the provision of a service so good that their customers will not be able to replace that relationship if buyers impose the sanction of delisting (see for example, Nicholson and Young, 2012). We had only a small number of suppliers available and were not able to test this proposition. However, we did find two interesting cases of preferential accounting treatment with long-term and trusted suppliers involving target cost contracts and open book accounting, discussed in the following section.

The situation is exacerbated by the role of retail buyers, who are alleged to be non-specialists and rotated between categories on a frequent basis. Linked into this is the problem of forecasts. One Director of the UK Firm simply said that their own forecasts for what consumers require are better than those of the retailers. Discussing the characteristics of better customers among the retailers, it was said that:

"Longer-term approach is probably the main thing. They understand crop timings better than other retailers, they have more stability than other retailers, therefore they have better understanding and there is more of a trusting relationship which works both ways. They are still hard on pricing, but at least you can plan."

Through the conversations, the observations of Hingley (2005) and others concerning the business models adopted by intermediary food supply businesses were confirmed: the intermediary offers themselves as a risk buffer between the customer and the supplier. For the customer, the range of suppliers that the grower-packer has in the UK, Spain and elsewhere, means that the intermediary mitigates the risk of the customer failing to provide year-round produce for consumers. For the supplier, they provide some guarantee of payment or custom that would be lost if the supplier worked directly with just one supermarket.

The pressure put on intermediaries to work to retailer forecasts was also contentious. The UK/Spanish Firm stated that:

"Supermarkets or intermediaries have a problem with forecasts and do not take [the volume] that you have programmed to grow into account. Then the problem is that there is no compensation from the customer [for poor forecasting], at least never directly, all you get is a little more strength [position] to negotiate the following year, we never receive compensation for losses."

The UK Firm stated that "Our sales can vary by $50 \%$ in a day and I am quite sure that consumption rate doesn't change that much and that can only be bad sales forecasting."

Although the performance risks of food production are weather and disease related, in all cases owners and managers saw their main risk as being commercial risk. This is a relational risk (Das and Teng, 2001) identified by our interviewees as loss of customer or supplier at little or no notice, which 
in turn is linked to the relative ease of substitution in the market for any fruit, salad or vegetable without premium qualities. The other aspect of commercial risk is loss of reputation because of a real or imaginary food safety incident.

The risks attached to growing crops, such as weather, disease and water shortage, are known and managed, although timing remains a "very high and uncontrolled risk factor" (Spanish Firm). Simply, you cannot ever guarantee that a crop will be ready on a particular day. Similarly, risks associated with transportation and delivery logistics are managed, with a very small number of penalties being received for late or non-delivery. Overall, the UK Firm and the Spanish Firm both stated that they achieved in excess of $99 \%$ of agreements with the retail customer. Commercial risk, on the other hand, is largely out of their control. One Director defined commercial risk as:

"...our customers and retailers being promiscuous with suppliers by chasing the cheapest grower all the time, by having no longevity for their source. It is very shortterm behaviour all the time and there's also the cancer of our industry, marginal costing" (Director, UK Firm).

Quality assurance programmes are the main risk management tool. The ability to deliver safe food, grown to specification and delivered on time provides protection against loss of custom and more opportunities for the development of long-term relationships.

"Really everyone is equal. There are suppliers who've spent more time working with us, with whom you have more affinity, value the relationship a bit more and you know well all their specifications, [these suppliers] know the customer, labelling, product type, the packaging they [the customer] want" (Purchaser, UK/Spanish Firm).

A significant amount of time is spent on achieving quality assurance certification and maintaining the documentation relating to certification. For some produce, supermarkets insist on certain certifications (for example, from the Soil Association in the UK for organic crops).

The longer-term relationships with growers that all three firms are developing show that some intermediaries are protecting growers and sharing risk in return for the benefits of that longer-term relationship in the form of information, advice, quality know-how and even, in some cases, guaranteed prices at times of catastrophe. The Managing Director of the Spanish Firm said about supplier relationships:

"We're close... well, there is an indication of prices, usually a week ahead, when we think this is what we will get. And at 21 days the price has been closed and the grower can come and collect your cheque, transfer, manage your money. What is very important to them is a commitment we have to communicate in 48 hours qualities and sizes, all because they will be paid by the sizes and qualities."

An example of protective working relationships arose during the study. In a case widely reported in Europe, an E. coli outbreak was linked to Spanish cucumbers. The Spanish Firm bought cucumbers from their suppliers anyway at the agreed price, in order to protect them from the loss of business. Demonstrating robustness in these crises is seen as a business opportunity, to secure future orders for the grower-packer and their suppliers. The Managing Director of the Spanish Firm explained that:

"It is true that it generated a brutal crisis [E. coli], that a company like this has cost us two and half million euros, is true. But then, that's the short term and in the medium and long, we generated a belief that it can be a business strategy... at this point, we have some growing conditions, pest control, tracking control, including environmental sustainability that currently very few competitors in the market, especially those coming from North Africa or elsewhere further away, can meet." 
From the literature on inter-organisational management controls, sharing of assets such as IT and accounting information are a means for both partners to gain competitive advantage (for example, Romano and Formentini, 2012; Schloetzer, 2012). Within fresh produce supply chains, there was no sharing of physical assets nor IT between the intermediaries and their customers in the firms interviewed. Orders and forecasts were received electronically, but had to be entered into the intermediaries' own IT systems. However, the intermediaries did use relatively sophisticated IT systems within their own businesses. One used 'LinkFresh', which is a small ERP system designed for the food industry, which has some functions such as communication with hand-held devices, but at the time we visited business intelligence report functions were still under development. The Spanish Firm had a very detailed accounting system, but found it difficult to keep it updated quickly enough to deal with the day-to-day changes in the business, so resorted to spreadsheets:

"Most of the information to make everyday decisions, we have to prepare manually with spreadsheets ourselves and in an artisan way...".

The UK Firm stated that it did not share their accounting information with customers, but would share information with 'loyal' suppliers and was looking to build a group of 25 or even 50 suppliers who would work closely with them on such a long-term basis.

We found no cases of open book accounting (OBA) such as that explored by Free $(2007,2008)$ between intermediaries and customers in fresh produce [6]. Performance data is provided in the form of reports and face-to-face interactions, but there is little or no sharing of financial accounting data. Between intermediaries and their suppliers, we did find one example of OBA and one of a target cost contract between the UK Firm and two very long-term specialist suppliers. The OBA was with a Spanish subsidiary who had been supplying them for over 20 years. The target cost contract enabled them to retain a specialist in growing premium potatoes using trickle irrigation who would otherwise not have been able to continue production without some guaranteed income.

We visited the Spanish supplier with whom the UK firm had the OBA agreement. The ownermanager of the supplier told us:

"...we have an agreement in which we share the benefit... we work with what we call open books, and they know our costs and we know their costs and we share the profits among us. With the rest of the customers/intermediaries, it is a pure and hard negotiation that we have to produce this amount, and this is the price. Other information is not shared in principle, detail is not shared except in a generic way such as how the year has gone, good or bad. That yes, but little more... a major advantage [Of OBA] is the fidelity - it is harder to lose that customer because you are sharing more. Another important advantage is that we are both interested in making the association work."

Whilst there were no other clear OBA arrangements, intermediaries did feel that they shared information with chosen suppliers, those committed to some extent to produce for a small number of customers rather than the whole trade. In the UK/Spanish Firm, one manager explained:

"We do mini-maxi pricing arrangements, we do five-year business plans or five-year land planning with some of our growers. Sourcing for life is a risk management strategy for our chosen growers. So we do quite a lot really in terms of agricultural support and business support, business development."

The Spanish co-operative, though, worked on a much more contractual basis and required a common software to be used. Hence, they were able to collate accounting and production data for analysis. 
"The grower... is supposed to work $100 \%$ with you, signs a contract where he undertakes to comply with all quality regulations, phytosanitary treatments. You have a control over... where they are located, you have a field notebook with each of the farms. That is, the grower who works with you, works fully, with all his plantation, and let's say with all confidence. He thinks that they're your growers, since they have been working with you 25, 30 years, then you have a very close relationship. So, it is not that there is a grower who today works with you or tomorrow works with another, has a farm with a company or has a farm with another, that is rare. The normal thing is that the grower has all his work scheduled, planned and controlled let's say by your technicians, by your commercials, doing that work."

Any open book element here is one-way, unlike the arrangement between the UK Firm and its Spanish subsidiary. The industry is characterised by a plurality of organisational forms, transactions and accounting methods, as we were told by a software firm who found creating a small ERP system for the industry far more convoluted than expected.

The target cost contract was acknowledged by both sides to be the first attempt to retain a supplier through a formal contract mechanism. The target cost element came at the suggestion of the supplier, who had been influenced by a technical paper published by CIMA on target costing in agriculture. The supplier was a grower of specialist potato crops and a leader in the adoption of trickle irrigation, which enabled them to restrict blemishes on salad potato and premium crops. However, their own calculations showed that they were being given no return for the management effort related to the innovative agronomy they applied. In addition, as managers, to supply premium products demanded by retailers, they had to find land for crop rotations, negotiate water access and other quite complex legal and financial matters beyond bringing their expertise in the physical aspects of growing. As a tenant farmer, their financial viability was precarious when the price received was based on marginal costing. The target cost contract allowed the intermediary to advance a price for potatoes based on a costing that included a management fee and to pay a premium if, and only if, the potatoes reached a quality threshold. The contract was perceived as a risk sharing rather than a value sharing arrangement. The grower-packer (the UK Firm), in funding the variable costs, also took some share of the risks of weather and bruising. However, the model does not seem to have been taken up elsewhere.

Outside OBA and the target cost contract, we found that expertise and know-how are shared, but interestingly this is mainly from the intermediary to the customer and from the intermediary to the supplier. Although supermarkets do employ some agronomists among their technical managers, it appears that significant reliance is placed on the intermediary to explain why they can or cannot fulfil a specification, and what is required to produce a crop. Buyers in fresh produce, it is alleged by all three firms, rarely have this knowledge, although more recently supermarkets do seem to be seeking employees from grower organisations. For suppliers, the agronomy, marketing and other expertise is shared as a value-added service to ensure quality of supply and retention of the supplier. Referring to the requirements of one customer (a sandwich producer), the Purchaser for the UK/Spanish Firm said that supplier relations are about:

"...quality audit and quality control. Travel to meet clients, to see exactly what clients do with products, teaching process of client transformation/manipulation of fresh product once it comes to England. To see how the tomato has to be a specific size for the slicer. Showing that [the] client needs the tomato either larger or smaller."

In some cases, to aid crop rotation and allow for growth in yields, suppliers and intermediaries may have land-sharing arrangements in place. The cost of research and development that benefits the customer and consumer is usually funded by upstream businesses and is seen by supermarkets as an 
opportunity for suppliers to differentiate themselves and increase their chances of gaining and retaining contracts. For example:

"Treatments that we have to perform are totally different, we try... also advised to keep the cost as low as possible, even establish help lines for certain issues; for example, this year to introduce the line of work biological control, the increasing of the costs is funded $50 \%$ by the grower and 50\% by us" (Managing Director, Spanish Firm).

The result is more reliable sources of higher quality produce. However, the industry is very visible competitors can see fields and transportation, and the products on supermarket shelves. Information sharing only takes place with trusted suppliers and customers. A UK Firm Director said:

"There is a lot of sensitive commercial information isn't there? We don't want our competitors getting hold of that".

The UK Purchaser for the UK/Spanish Firm said more bluntly:

"Information on costs, [UK/Spanish Firm] does not provide cost information to customers. Simply, it is an auction, quoting a price, the profit margin is determined by [UK/Spanish Firm]. If [UK/Spanish Firm] reduced the price paid to suppliers, [there would be] more chances of getting the contract with customers."

The Spanish Firm also admitted using a form of arbitrage based on their own accounting and performance measurement records. Retailers were ranked in terms of prices paid and reliability in paying, and where supply was short, the co-operative managers would look at where they could get the most margin for their supply on particular days and prioritise supply accordingly. However, at the same time, the grower-packers did feel a sense of responsibility to the suppliers. The UK Sales Manager of the UK/Spanish Firm stated:

"It's important that the growers in Spain get a good return and if they don't get a good return they are out of business. I mean there are so many growers now that can't carry on."

He continued:

"The main risk is industry speculation... not back-to-back deals, but contracts, a grower. The idea behind our business is actually that whatever business, whatever contracts we have in place, we do a deal direct with the grower in Spain or wherever it may be."

The lack of fully integrated information systems and other resources, and the relatively easy substitution of products, leads to a fragmentary and incomplete supply chain. Performance measures are used extensively within the intermediaries and cover internal processes, quality, customer profitability, delivery to customers, staff development and finance. In terms of negotiation with retailers, quality and delivery specifications are set by the retailer/caterer.

The role grower-packers play in the network is to turn the demands of supermarkets and other major outlets, and the growing cycles of producers, into workable but ever-changing plans that achieve 'on time, in full, to specification' deliveries around $99 \%$ of the time (all three firms claimed to hit this target). They advise on what is technically possible and achieving growing conditions in which plants meet the specifications with the minimum of waste. Unlike the bigger manufacturing firms in the industry selling long-established brands, the businesses that we examined have little protection in terms of intellectual property and, with a few exceptions, are using generic technologies. 
In one case, an interviewee told an anecdote about this situation, how they (the grower-packer) had pointed out to the customer the long record of the firm in supplying on time, in full and to specification. The next line of defence was that they had all the certifications in place, and another supplier might take time to acquire these. The final line of defence was that the price offered was so far below the cost of production as to be unviable. They lost the contract for that item and others, but the customer came back some weeks later offering a better price, not being able to match the quality and delivery criteria elsewhere. Asked how often this might happen, the grower-packer suggested that it might be once or twice a year.

The strategic aims of the intermediaries we spoke to were to establish long-term positive cashflows from current activities and to continually look for opportunities to develop new revenue streams. The alternative is to exit the industry, or product lines, but survival of the firm is their main driver. The grower-packer businesses, for example, may only have emerged in their current form in the last 20 years, but they are built on farming businesses that go back three generations or more.

\section{Discussion}

We found that the business model of the intermediaries was based on their ability to form a risk buffer between primary producers of fresh produce and the major supermarket outlets for that produce. We also found that the companies may have detailed and relatively sophisticated accounting and control practices. When it comes to negotiating with category managers and buyers though, the only measure used in discussions between intermediaries and supermarkets is that of 'on time, in full, to specification' delivery. Our case firms met this99\% of the time. In studies of integrated supply chains, researchers see discussions where overhead costs and margins are on the table. It is almost impossible to get across that this does not happen in the food industry as a matter of course. The authors have taken part in several research projects, consultancies and industry meetings with suppliers and have been told on every occasion that the fresh produce buyers do not allow discussion of costs. As the interviewees from the UK firm told us, they save the arguments on unit cost for those occasions when the buyers demand a price that is completely unrealistic and cannot be evened out through the basket of sales to that supermarket. In a well-publicised argument in 2016, Unilever demanded that the UK's largest supermarket (Tesco) increase the price paid to them for the popular product 'Marmite' in the UK to cover increased costs through currency exchange following the UK referendum vote to leave the EU, to which Tesco reacted by threatening to withdraw the product from their shelves. That even Unilever and Nestlé (Nicholson and Young, 2012) have arguments with supermarkets on this same issue of overhead cost recovery indicates that those with less market position or without brand identification are going to experience greater difficulties. Following the Tesco scandal in 2014/15, their new CEO announced that one of their changes in practice would be "to no longer negotiate on marginal cost" (Stones, 2015, p.1) a promise that needs follow up research.

There are isolated examples of OBA, target cost contracts and overhead analysis between intermediaries and their supplier, but not with their customers. Our first question was how measurement, risk management and communication of accounting information is used by intermediaries in an allegedly unfair commercial environment. One answer is that it is used to ensure that thin margins can be obtained by using detailed cost analysis within the company Also, it is used to play an ever-changing win-lose game with the major supermarkets. The Spanish cooperative produced rankings of transactions between supermarkets and would effectively arbitrage between orders where there was some scarcity of supply. The managers in the UK/Spanish firm produce weekly bulletins based on costs for their suppliers, and all the intermediaries worked hard with their suppliers to "make price a secondary issue" (as the Spanish firm told us) in order to maintain their ability to call on suppliers to fulfil orders from customers. They profess to provide advice and support for growers to allow both the producers and themselves to survive as family businesses, aiming to have better relationships with the growers than they as intermediaries have 
with their retail customers. One of the limitations of this study is that we were not able to talk with enough suppliers to test these assertions. Evidence from the few long-term suppliers and independent small firms to whom we did speak generally acknowledged that the intermediaries were supportive and contributed to the survival of their businesses.

Frances and Garnsey (1996) describe the control of producers through quality metrics, but this is a very narrow view of accounting. We find that financial metrics are very rarely discussed and information sharing is very restricted, even in long-term supply relationships. In the context of global markets, Frances and Garnsey (ibid.) also found evidence that supermarkets saw the new growerpackers as intermediaries between themselves and growers around the world. When supply fell short in England, or if it was out of season, then fresh produce could be sourced from Spain and other countries where the seasonal patterns are different. What was not evident in the 1990s was the extent to which supermarkets would move cost and risk onto these intermediaries. Furthermore, the level of integration between information technology systems is not as sophisticated as pictured by Frances and Garnsey (ibid.).

The next question concerns the extent to which the accounting and control practices observed support perceptions that suppliers in supermarket-dominated supply networks are treated unfairly. This divides into two lines of argument: the first concerns the distribution of profit and value in the industry and the second concerns the nature of the relationships of domination and subordination.

Our evidence supports earlier studies showing that suppliers of fresh produce are engaged in a winlose relationship with the supermarkets (Frances and Garnsey, 1996; Cox and Chicksand, 2005; Hingley, 2005; Bowman et al., 2013; and others). They are subject to opportunistic and adversarial trading (Bowman et al., 2013) in a market that one UK Firm interviewee described as promiscuous. 'Profit-snatching' is alleged and supermarkets are seeking $40-50 \%$ (or more) margins on their price to the consumer (Bowman et al., ibid.). UK fresh produce grower-packers are achieving average net margins of $1 \%$ and are financed heavily by the owners themselves. Wage data shows clearly the high levels of minimum wage and illegal wages in the global system. This evidence of the uneven distribution of value and profit is well supported. Downward pressure on prices is driven by investoranalysts seeking higher returns to shareholders in the major supermarkets and food manufacturing sector. Although net margins in food retail might be regarded as low (currently around $3.4 \%$ ) this still allows high absolute amounts of dividends to be paid from the sector.

From our data, the Grocery Code of Conduct and studies such as Duffy et al. (2013), it is evident that there are some practices that are not indicative of fair relationships, including the way in which commercial income is raised from suppliers by supermarkets (Grimes, 2005; GCA, 2016; and others). We believe that restriction of the discussion between supermarket representatives and intermediaries to narrow measures that exclude overheads and supplier margins could also be indicators of unfair relationships.

To evaluate this, the framework offered by Néron (2015) for the audit of relational justice is useful. The key concepts here are 'voice' and 'sphere differentiation'. This offers two ways by which accounting and control can add to the discussions on relational justice and on how 'justice as fairness' applies in a commercial environment.

Voice has been explored in terms of employee participation and workplace democracy (Rawls, 2001; Hsieh, 2005; Néron, 2015) but not, as far as we can see, in terms of supply chain. A simplified explanation is that the voice of the intermediary is curtailed in their relationships with their supermarket customers, but that they attempt to allow their suppliers a voice in those relationships. Particularly in terms of the European co-operatives, which consist of growers as members, some level of equality is assumed between those negotiating with the buyers and those doing the growing. In the UK Firm, one of the Directors evinced an aim to consolidate their suppliers into a trusted 
group of around 50 who, in return for support, advice and near-guaranteed sales, would receive more financial information and have a voice in the direction the company was going.

Sphere differentiation is also explored in the literature in terms of organisational hierarchies. Anderson (2009 and elsewhere), has explored the need for organisations to retain some level of hierarchy related to decision-making to 'get the job done', but asserts that superior authority is attached to offices and roles, not to people. Outside of the workplace, the authority one individual has over another does not carry beyond the sphere of the organisation. However, as Néron (2015) and others point out, this is somewhat fragile as a concept, as one's work status and pay affects what opportunities you have in society in general. Here, we should consider whether the hierarchical dominance relationship assumed by supermarkets over intermediaries is appropriate in terms of sphere differentiation.

Does the relationship function in the same way as a bureaucratic power relationship within organisations: that is, a purely functional use of power that should be confined within the sphere of operations? Drawing on interviews from the UK firm, supermarkets want the prices that come from trading and the quality that comes from a long-term integrated relationship. In a trading relationship, there is no exercise of power, only a temporary relationship that lasts the length of each transaction and may be exercised at arm's length. If the relationship is voluntary and enacted in accordance with some external standards governing (for example, weights and measures, hygiene, safety and payment terms), then it may be a fair relationship. However, if one party or social conditions force the seller to sell at below cost of production for example, we might say that the transaction is unfair due to a temporary relationship in which one party is coerced by the other and has not equality of opportunity.

In terms of the other auditable qualities identified by Néron (2015), it can be argued that these relationships are voluntary and each player is able to exit freely; no-one forces you to be in horticulture or to sell to supermarkets. This is a difficult point. Consumers buy most of their fresh produce from supermarkets. Grower-packers have evolved a business model to meet that demand. The arguments around alternative food systems and the moulding of consumers to fit the supermarket model are outside the scope of this study, but are acknowledged as other elements of the overall argument. The supermarket provides the largest marketplace and run as people providing space in a market and marketing expertise (Burch and Lawrence, 2007; Bowman et al., 2013) - they are not themselves old-fashioned grocery stores, albeit that might be their origins. Hence, most growers have no option but to sell through the supermarkets via an intermediary. Exit means losing the family farm. For the UK economy, this means greater reliance on fresh produce imports each year. Related arguments concerning the maintenance of the UK industry are out of our scope here.

Our findings confirm that the fresh produce supply network in the UK, as in other developed countries such as the USA, Canada and Australia, is a "very peculiar monopsony" (Harvey, 2007, p.58). The power now wielded by the supermarkets is different to that envisaged by Frances and Garnsey (1996) where IT and accounting would be used to dominate suppliers and their methods of operation. Instead, it is a relational power that is characterised by some level of perceived promiscuity rather than related to a small number of brand or own label manufacturers as in Free $(2007,2008)$. This relational power is manifest in practices aimed to drive down prices and to negotiate on a marginal cost basis, the ability to restrict the voice of the supply chain partner in terms of negotiation on price using evidence from accounting data, and the transfer of risk of nonsupply or customer complaint to the intermediary. Conversely, the grower-packers aim to absorb the risk for growers in terms of having multiple customers for the supply from smaller farms.

This distortion of relational power leads to a high proportion of those working in the industry in the UK being paid minimum wages and growers in the UK and abroad being on or below the poverty 
line. They do not have the fair opportunities that good nutrition, access to other social goods and advancement that others have (Guthman, 2011). Owner-managers of grower-packers receive decent salaries, but the returns appear not to be commensurate with effort, the risk assumed or their societal role, although we do not have sufficient data in this project to follow this line of argument further. A frequent argument put to us when we have presented the paper is that farmers are not poor, own land and receive hefty subsidies, which is largely a misconception. In fresh produce, there are no subsidies and the income of most growers (who are tenants and not land owners) is below that of other workers earning an average wage (Lines, 2008).

The supermarkets that act differently are those attempting to integrate and shorten their supply chains (Bowman et al., 2013), creating longer-term relationships. All the retailers profess this aim, but it is most evident in the premium shops and the 'discounters', who have risen quite rapidly in the UK since 2014 (that is, after the Bowman et al. report). They have only a minority market share.s . Premium retailers, our interviewees pointed out, do try to maintain longer-term relationships and ameliorate risk, but will still drive hard on price. The discounters were cited as being hard on price but better to deal with because they will take the produce that they have ordered, do not use commercial income schemes, and make it easier for the growers to plan on a long-term basis.

From our findings, we can contribute to the literature by isolating accounting as an element of relational unfairness. The unfairness comes down to three points: the severe restrictions on the use of accounting data and financial information in negotiations between supermarkets and intermediaries; the use of marginal costing as a basis for negotiation; and the transference of risk without commensurate reward.

The relationship with the buyer appears to be the central problem, as in Free $(2007,2008)$ and Bowman et al. (2013). Grimes defines buyer power as "the ability of a buyer to significantly influence the terms of a purchase for reasons other than efficiency" (2005, p.565). Supermarket buyers tend to be rotated frequently, allegedly to prevent too close a relationship forming that might jeopardise pricing. They are seen to be inexperienced in the field and without agronomy or financial knowledge. Stories of pressure placed on suppliers to provide increased volumes, variations in specification or offers at short notice, at the risk of penalties including delisting, are often heard in the news media, although Duffy et al. (2013) believe that as supermarkets become more aware of the benefits of long-term supplier relationships this is becoming less usual. Furthermore, as we saw with the 2014 Tesco plc case, buyers have worked previously under regimes of based on reducing costs and increasing commercial income, and at the time of the study were rewarded on the basis of margins achieved.

Finally, what accounting and control practices would be indicative of fair commercial relationships? In an ideal fair society, as envisaged by Rawls, there would be publicly recognised rules of cooperation which follow naturally from getting the basic structure of society in place, where there is an ongoing project of social co-operation. No game-play would be required; either OBA or a trust that each side was putting forward reliable information without the objective of cheating the other would form the basis of negotiations. Any penalties would be stated and agreed by both sides. There would either be long-term relationships in which both sides used the accounting and control information to improve margins for all parties, perhaps through a target cost contracting mechanism, or short-term trading on open markets where the rules of co-operation were accepted and understood. Risk would be distributed fairly and the taking on of risk rewarded commensurately.

However, given a non-ideal society, the balance of relational power would be improved between food supply network partners if relational resources (Anderson, 2007; Cordelli, 2015) were shared in ways that more resemble Rawls' 'justice as fairness'. Following Néron (2015) again, this would mean a level of trustworthiness that allows discussion of increased overhead costs in ways that neither 
side feel taken advantage of by the other. In terms of sphere differentiation, it would allow the management of risk to be more properly delineated and recognised. This may mean that the power in the supply network is recognised as being the intermediaries, and that they are able to exercise that power only for the purpose of ensuring a reasonable and equitable supply of fresh produce to consumers. In other words, intermediaries could not then exploit the power that they have been assigned to exact abnormal payments from supermarkets within long-term relationships. There is another study to be carried out here, because the balance of power has in the past fifty years been more in favour of manufacturers and processors (see, for example, Duke, 1989) and the current situation of category management is the story of the retailers' ability to re-orientate the power in the system to themselves. Relational justice, however, would suggest that any dominance is subscribed only to those situations in which it is needed to achieve an end. It could be argued that this is the current situation (supermarket shelves are full), but clearly this comes at a cost to society, and to the least advantaged in the system.

Elsewhere in the business ethics and corporate governance literature, intermediary companies are seen as key to achieving 'justice as fairness'. Some writers argue for fair markets rather than fair negotiations by individual firms. Free markets might generate wealth, but they do not distribute wealth fairly (Sud and VanSandt, 2011; Schmidt, 1992). A fair market is one, according to Sud and VanSandt (2011), that opens multiple global opportunities for smaller businesses supported by technology and with a regulatory system that allows entrepreneurship. They demonstrate how the farm-to-market network of suppliers of soybeans in India was transformed by the intermediary company buying and trading beans on these principles, resulting in a fairer distribution of the value in the network. The intermediary essentially created a fairer market within their supply chain which, in turn, increased the quality and value of the soybeans which they then traded on open markets. The success of this initiative also increased sales of the intermediary's e-platform developed for their suppliers. However, their work does not indicate whether a more closed fair market could be replicated on a national or international scale, but does indicate that fair markets might be the responsibility of individual firms. The unanswered question is whether 'super middlemen', such as those in our study, could be instrumental in constructing fair markets that allow small growers to thrive. We have limited evidence to suggest that this could be the case, but a follow-up study that focuses on smaller suppliers is required to test this further.

\section{Conclusion}

Our first contribution is to extend the sparse accounting and control literature on intermediaries by providing further empirical evidence of accounting and control practices in such firms. Like Bowman et al. (2013), we find an opportunistic environment in which cost accounting and performance measurement are used minutely within individual businesses to maintain very slight margins and a positive cash flow, but where intermediaries are frustrated in their attempts to hold negotiations with customers using financial information. Our empirical data shows that the findings of Frances and Garnsey (1996) represent a particular instance in fresh produce supply to supermarkets and that although their analysis of the assumption of power by supermarkets is relevant, the particular accounting and information technology practices they envisage have not materialised as expected. The work of Free $(2007,2008)$ and Neu et al. (2014) examine non-food intermediaries. We demonstrate that further comparative evidence is needed to establish the patterns of practice within intermediary firms and to elucidate further the role played by managers within intermediaries in maintaining or changing existing systems.

Our second contribution is to initiate a discussion in accounting about fair commercial relationships within supply networks based on the theories of justice. There are a small number of papers examining theories of justice through financial reporting (Power, 1992; Archer, 1996; Flower, 2010), but none in the areas of management accounting and control. There is some limited theoretical discussions in the wider organisational literature, such as marketing and supply chain management.. 
Theories of justice are discussed in business ethics and corporate governance but there is limited empirical research. Papers such as Bowman et al. (2013, p.313) end with a generalised call for policymakers to maintain "a sustainable and profitable supply chain contributing to national objectives such as food security and continuous employment", which must be part of a fair basic structure. However, they do not evoke any theoretical basis for their arguments. We are concerned with isolating how accounting and control are entwined in the arguments for relational justice and social justice.

Fundamentally, in both the ideal and non-ideal situations, 'justice as fairness' within a basic structure of social co-operation patently does not exist as the system does not work in favour of the least advantaged in the system (the lowest paid workers) who do not have fair equality of opportunity in society. The underlying political issue is that of cheap food provision and this is the area in which accountants could start to have an impact, by looking at where costs are incurred in the system in terms of waste, at fair pricing and the communication of accounting and performance measurement information in negotiations in ways which have perceived fair outcomes. However, the study of food systems and food security is complex, and further projects would have to be interdisciplinary to understand the potential unintended consequences of changed practices. This study is restricted in scope to intermediaries, a small number of suppliers and others (brokers, consultants) working closely with those in the fresh produce supply network. Future studies would include consumer perspectives, smaller horticultural suppliers, supermarket chains in other developed and emerging countries, and consideration of other supply networks in countries also maintaining a year-round supply to the UK, such as Kenya, Morocco and Chile. Then it would be possible to undertake an analysis of what a social contract for food systems would look like if 'justice as fairness' is to be achieved throughout society[8]. Whilst there are many popular studies suggesting remedies, none look at the implications of individual financial transactions and accounting practices for how food is distributed through societies.

The interesting suggestion towards the end of the analysis is that intermediaries might play a pivotal role in finding 'justice as fairness' within the system, a role that is not yet realised. A follow-up longitudinal study to see whether the plans to develop more long-term relationships with a pool of key suppliers, such as the UK Firm was exploring at the time of the study, would provide further evidence of whether intermediaries can perform this role in networks. Such a study would examine the extent to which accounting practices were developed and information shared had contributed to relational resources such as trust and transparency, whether accounting was given more of a voice, and the extent to which dominance was reduced to appropriate spheres of bureaucratic need, which the work of Anderson and others suggest might be indicators of relational justice.

\section{Footnotes}

[1]

An indicative source of evidence for this figure of 1-2\% can be found in the Agribusiness Industry Benchmarking Report (2016) published by Key Note (https://www.keynote.co.uk/benchmarking-report/agriculture-chemical/agribusiness-industry-benchmarking) Taking the sector Arable Farming and Horticulture section and removing the non-grower packers, there is a 3 year average from $2014-2016$ of $1.05 \%$ across the sector. The report also contains evidence of lending and other factors, supporting what we found in the financial reports of our case companies, not given here for reasons of anonymity. Firms with higher margins tend to be smaller and supplying niche crops for export as well as domestic use.

[2]

The Grocery Code Adjudicator's role was established in 2013 to "ensure supermarkets treated their supplier lawfully and fairly" following a 
Competition Commission market investigation in 2008 where it was found that "while the sector was broadly competitive, some retailers were transferring excessive risk and unexpected costs to their direct suppliers" (GCA, 2014, p.4). Bowman et al. (2013) and others remain highly critical of the 2008 investigation and, in other countries, antitrust reviews of grocery retailers appear to be undertaken on a regular basis (Kobel et al., 2015).

Category management and earlier efficient consumer response initiatives grew out of a long power struggle between manufacturers and retailers. Although supermarkets are now perceived as having the upper hand, this was not seen as the case in the 1970s and 1980s, where they felt dictated to by the big brand manufacturers (Clarke, 1985; Frazier and Kale, 1989). Importantly, the introduction of packaged fresh products as a significant element of the offering in supermarkets is a development of this period.

There are atomistic producers and consumers on either side of the food supply chain. Therefore, in the last 15 years as the top four UK supermarkets (Tesco, Sainsbury, Asda and Morrisons) have forged market dominance accounting for $62 \%$ of the grocery market with the higher end outlets (Waitrose, Marks and Spencer, and The Co-operative) and the discounters (Aldi and Lidl) accounting for another $20 \%$ of the market (DEFRA, 2014). The big four supermarkets have become vast marketplaces, including banking and insurance services, online markets, non-food goods and pharmaceuticals, as well as all types of food, thus they have obtained relational power over both consumers and suppliers (Cortesen and Kumar, 2005).

Such a society has reasonable pluralism, as the idea "of all members accepting the same comprehensive doctrine is impossible. But democratic citizens holding different comprehensive doctrines may agree on political conceptions of justice" (ibid.). Political justice is contained in the basic structure of a wellordered society with a fair system of co-operation. Other fundamental principles are the notions of an original position, citizens as free and equal persons and public justification. The original position is perhaps the better known concept as it features the term 'veil of ignorance', meaning that parties involved are limited in that they should not know anything that enables them to make a value judgement of each other. That is, they are ignorant of someone's race, status, sexual preferences and so on. Hence, their conceptions of political justice are unaffected by these matters.

In the USA, Walmart have made open book accounting via their own platform a pre-requisite for suppliers, but such enforcement is not permissible in Europe. Tesco in the UK does run the Sustainable Dairy Group for its milk suppliers on an open book basis, but there are few other examples.

In 2016, the discount stores Lidl and Aldi received considerable publicity as being the only supermarkets to announce that their staff would be paid above the living wage proposed by the government (Fleming, 2017). Farm workers in the UK now get the minimum wage since the abolition of the Agricultural Wages Board in 2013, but often not much more, and immigrant labour is an issue in both the UK and Spain (Scott, 2013). At the time of writing, Aldi is the only supermarket to sign up to the National Farmers' Union code for suppliers of horticultural products (NFU, 2015) and to state on its website that it does not seek commercial income from suppliers. 
This is very close to the concept of 'food justice', a growing international activist movement. To avoid confusion with our arguments of 'justice as fairness', we chose not to discuss 'food justice' but acknowledge here that future work would explore the applications of our findings for that public discourse.

\section{Acknowledgements}

The support of the CIMA General Charitable Trust is gratefully acknowledged. Furthermore, this work has been partially funded by the SEJ-1933 research project of the Andalusian Government and ECO2014-57023-P funded by the Ministry of Education and Science (Spain). We are also grateful to the two anonymous reviewers of this paper for their insights and advice. Thanks are also due to those who commented on earlier versions of the paper, including Dale Tweedie, Russell Craig, Julia Mundy and participants at the Critical Perspectives in Accounting Conference 2014 and the British Accounting and Finance conference 2016.

\section{References}

Abdel-Kader, M., \& Luther, R. (2006). Management accounting practices in the British food and drinks industry. British Food Journal, 108(5), 336-357.

Anderson, E. (2007). How should egalitarians cope with market risks? Theoretical Inquiries in Law, 9, 239-271.

Anderson, E. (2009). Toward a non-ideal, relational methodology for political philosophy: comments on Schwartzman's challenging liberalism. Hypatia, 24(4), 130-145.

Anderson, E. (2010). The imperative of integration. Princeton: Princeton University Press.

Anderson, E., \& Pearce, N. (2012). Juncture interview: Elizabeth Anderson. Public Policy Research, 19(3), 188-193.

Angdal, H., \& Nilsson, U. (2010). Different open book accounting practices for different purchasing strategies. Management Accounting Research, 21(2), 147-164.

Archer, S. (1996). The ethics of creative accounting. Science and Engineering Ethics, 2(1), 55-70.

Bowman, A., Froud, F., Johal, S., Leaver, A., \& Williams, K. (2013). Opportunist dealing in the UK pig meat supply chain: trader mentalities and alternatives. Accounting Forum, 37(4), 300-314.

Burch, D., \& Lawrence, G. (2007). Supermarkets and agri-food supply chains: transformation in the production and consumption of foods. Cheltenham: Edward Elgar.

Callado, A. and Jack, L. (2017) Relations between Usage Patterns of Performance Indicators and the Role of Individual Firms in Supply Chains, Journal of Applied Accounting Research, In Press.

Clarke, B. (1985). The diversity of the UK food market. Retail and Distribution Management, 13(1), 14-19.

Clarke, R., Davies, S., Dobson, P., \& Waterson, M. (2002). Buyer power and competition in European food retailing. Cheltenham: Edward Elgar. 
Cooper, R., \& Slagmulder, R. (2004). Interorganizational cost management and relational context. Accounting, Organizations and Society, 29(1), 1-26.

Cordelli 2015 Justice as fairness and relational resources. The Journal of Political Philosophy. 23(1), 86-110.

Corsten, D., \& Kumar, N. (2005). Do suppliers benefit from collaborative relationships with large retailers? An empirical investigation of efficient consumer response adoption. Journal of Marketing, 69, 80-94.

Cox, A., \& Chicksand, D. (2005). The limits of lean management thinking: multiple retailers and food and farming supply chains. European Management Journal, 23(6), 648-662.

Cox, A., \& Chicksand, D. (2007). Are win-wins feasible? Power relationships in agri-food supply chains and markets. In: D. Burch \& G. Lawrence, Supermarkets and agri-food supply chains: transformation in the production and consumption of foods (pp. 74-99). Cheltenham: Edward Elgar.

Das, T. K., \& Teng, B. S. (2001). Trust, control, and risk in strategic alliances: an integrated framework. Organization Studies, 22(2), 251-283.

Dekker, H. C., Sakaguchi, J., Kawai, T. (2013). Beyond the contract: Managing risk in supply chain relations. Management Accounting Research, 24(2), 122-139.

DEFRA (2014). Food statistics pocket book 2014. London: DEFRA.

Duffy, R., Fearne, A., \& Hornibrook, S. (2003). Measuring distributive and procedural justice: an exploratory investigation of the fairness of supplier-retailer relationships in the UK food industry. British Food Journal, 105(10/11), 682-694.

Duffy, R., Fearne, A., Hornibrook, S., Hutchinson, K., \& Reid, A. (2013). Engaging suppliers in CRM: the role of justice in buyer-supplier relationships. International Journal of Information Management, $33,20-27$.

Duke, R. C. (1989). A structural analysis of the UK grocery retail market. British Food Journal, 91(5), 17-22.

DuPuis, E. M., Harrison, J. L., \& Goodman, D. (2011). Just food? In: A. Hope Alkon \& J. Agyeman, Cultivating food justice: race, class and sustainability (pp. 283-308). Cambridge, MA: MIT Press.

Fayard, D. Lee, L.S., Leitch, R. A. and Kettinger, W. J. (2012). Effect of internal cost management, information systems integration, and absorptive capacity on inter-organizational cost management in supply chains. Accounting, Organizations and Society, 37(3), 168-187.

Fearne, A., \& Taylor, D. H. (2006). Towards a framework for improvement in the management of demand in agri-food supply chains. Supply Chain Management: An International Journal, 11(5), 379384.

Fearne, A., Duffy, R., \& Hornibrook, S. (2005). Justice in UK supermarket buyer-supplier relationships: an empirical analysis. International Journal of Retail \& Distribution Management, 33(8/9), 570-582. 
Fishman, C. (2006) The WalMart Effect: How the World's Most Powerful Company Really Works--and Howlt's Transforming the American Economy. London: Penguin Books.

Fleming, P. (2017). Wages hikes at Aldi and Lidl are good news. But don't get too excited. The Guardian 9 January 2017 available at https://www.theguardian.com/commentisfree/ 2017/jan/09/lidl-aldi-national-living-wage-supermarkets. Last accessed on 25 March 2017.

Flower, J. (2010). Accounting and distributive justice. Abingdon: Routledge.

Fox, T. (2013). Global food: waste not, want not. Cambridge: Institute of Mechanical Engineers. Available at URL: http://www.imeche.org/knowledge/themes/ environment/global-food.

Frances, J., \& Garnsey, E. (1996). Supermarkets and suppliers in the UK: system integration, information and control. Accounting, Organizations and Society, 21, 591-610.

Frazier, G. L., \& Kale, S. H. (1989). Manufacturer-distributor relationships: a sellers' versus a market buyers' perspective. International Marketing Review, 6(6), 7-26.

Fredenburgh, J. (2015) Supermarkets blamed as food companies in financial distress doubles. Farmers Weekly 20 April 2015 available online at http://www.fwi.co.uk/business/supermarketsblamed-as-food-firms-in-financial-distress-doubles.htm.

Free, C. (2007). Supply-chain accounting practices in the UK retail sector: enabling or coercing collaboration? Contemporary Accounting Research, 24(4), 897-933.

Free, C. (2008). Walking the talk? Supply chain accounting and trust among UK supermarkets and suppliers. Accounting, Organizations and Society, 33, 629-662.

Freeman, S. (2007). Rawls. Abingdon: Routledge.

GCA (2014). Groceries code adjudicator annual report and accounts 23 June 2013-31 March 2014. London: Her Majesty's Stationery Office.

GCA (2016). Groceries code adjudicator investigation into Tesco plc. 26 January 2016. London: Her Majesty's Stationery Office.

Ghosh, J. (2010). The unnatural coupling: food and global finance. Journal of Agrarian Change, 10(1), 72-86.

Grimes, W. S. (2005). Buyer power and retail gatekeeper power: protecting competition and the atomistic seller. Antitrust Law Journal, 2, 563-588.

Guthman, J. (2011). Weighing in: obesity, food justice and the limits of capitalism. Los Angeles: University of California Press.

Harvey, M. (2007). Supermarkets and asymmetries of economic power. In: D. Burch \& G. Lawrence, Supermarkets and agri-food supply chains: transformation in the production and consumption of foods (pp. 51-73). Cheltenham: Edward Elgar.

Heath, J., Moriaty, J., \& Norman, W. (2010). Business ethics and (or as) political philosophy. Business Ethics Quarterly, 20(3), 427-452.

Hingley, M. K. (2005). Power imbalance in UK agri-food supply channels: learning to live with the supermarkets? Journal of Marketing Management, 21(1-2), 63-68.

Hsieh, N. (2005). Rawlsian justice and workplace republicanism. Social Theory and Practice, 31(1), $115-142$. 
Hsieh, N. (2009). Does global business have a responsibility to promote just institutions? Business Ethics Quarterly, 19(2), 251-273.

Hunt, I. (2010). How egalitarian is Rawls's theory of justice? Philosophical Papers, 39(2), 155-181.

Jack, L. (2007). Accounting, post-productivism and corporate power in the UK food and agriculture industry. Critical Perspectives in Accounting, 18(8), 905-931.

Jeacle, I., \& Carter, C. (2012). Fashioning the popular masses: accounting as mediator between creativity and control. Accounting, Auditing and Accountability Journal, 25(4), 719-751.

Kobel, P., Pranvera, K., \& Kilpatrick, B. (eds.) (2015). Antitrust in the groceries sector \& liability issues in relation to corporate social responsibility. New York: Springer Publishing.

Lines, T. (2008). Making poverty: a history. London: Zed Books.

Néron, P-Y. (2015). Rethinking the very idea of egalitarian markets and corporations: why relationships might matter more than distribution. Business Ethics Quarterly, 25(1), 93-124.

Neu, D., Rahman, A.S., Everett, J. (2104) Accounting and sweatshops: enabling coordination and control in low-price apparel production chains. Contemporary Accounting Research, 31(2), 322-346.

NFU (2015). Aldi's commitment to UK growers. Available online at URL:

https://www.nfuonline.com/archived-content/archived-news-content/news/archived-newscontent-pre-nov-2015/aldis-commitment-to-uk-growers/ Last accessed on 25 March 2017.

Nicholson, C. \& Young, B. (2012). The relationship between supermarkets and suppliers: What are the implications for consumers? London: Consumer International.

Nozick, R. (1974). Anarchy, state and utopia. New York: Basic Books.

Nussbaum, M. (2003). Capabilities as fundamental entitlements: Sen and social justice. Feminist Economics, 9(2-3), 33-59.

Poddar, A., \& Donthu, N. (2011). What do we know about trade promotions? Contributions, limitations, and further research. Journal of Promotion Management, 17(2), 183-206.

Power, M. (1992). On the idea of a conceptual framework for financial reporting. In: M. J. Mumford \& K. V. Peasnell (eds.), Philosophical perspectives on accounting: essays in honor of Edward Stamp (pp. 44-61). London: Routledge, pp.44-61.

Rawls, J. (1971). A theory of justice. Cambridge, MA: Belknap Press.

Rawls, J. (2001). Justice as fairness: a restatement. Cambridge, MA: The Belknap Press of the Harvard University Press

Romano, P., \& Formentini, M. (2012). Designing and implementing open book accounting in buyersupplier dyads: a framework for supplier selection and motivation. International Journal of Production Economics, 137(1), 68-83.

Schloetzer, J. D. (2012). Process integration and information sharing in supply chains. The Accounting Review, 87(3), 1005-1032.

Schmidt, V. H. (1992). Adaptive justice: local distributive justice in sociological perspective. Theory and Society, 21(6), 789-816.

Scott, S. (2013). Migrant-local hiring queues in the UK food industry. Population, Space and Place, 19(5), 459-471. 
Singer, A. (2015). There is no Rawlsian theory of corporate governance. Business Ethics Quarterly, 25(1), 65-92.

Stones, M. (2015). Tesco's boss apologises to suppliers for past mistakes. Food Manufacture, 7 October.

Sud, M., \& VanSandt, C. V. (2011). Of fair markets and distributive justice. Journal of Business Ethics, 99(1), 131-142.

The Daily Telegraph (2013). Supermarkets pulled lower as Tesco is taken to task over margins; market report. 3 December, Business Section, 7.

The Economist (2015). Retailers and suppliers rebates: buying up the shelves. 18 June, available online at http://www.economist.com/news/business/21654601-supplier-rebates-are-heart-somesupermarket-chains-woes-buying-up-shelves Last accessed: 25 March 2017. 